\title{
PENGEMBANGAN MEDIA POP CULTURE UP RUMAH ADAT JAWA UNTUK PEMBELAJARAN MENYUSUN TEKS DESKRIPSI PADA PESERTA DIDIK SMP KELAS VII
}

\author{
Dewi Woro Ambarsari ${ }^{1}$, Bambang Hartono ${ }^{2}$ \\ Universitas Negeri Semarang \\ ambarsary60@gmail.com ${ }^{1}$, bambanghartonounnes@yahoo.co.id ${ }^{2}$
}

\begin{abstract}
Abstrak
Tujuan penelitian ini adalah mendeskripsi karakteristik kebutuhan media pop culture up rumah adat Jawa untuk pembelajaran menyusun teks deskripsi pada peserta didik SMP kelas VII, mengembangkan media, dan mendeskripsikan penilaian ahli terhadap media pop culture up rumah adat Jawa untuk pembelajaran menyusun teks deskripsi pada peserta didik SMP kelas VII. Penelitian ini dilakukan dengan menggunakan pendekatan Research and Development $(R \& D)$. Sumber data penelitian ini adalah siswa, guru, dan dosen ahli. Teknik pengumpulan data kebutuhan penelitian ini menggunakan kuesioner. Teknik analisis data menggunakan teknik analisis deskriptif kualitatif. Hasil penelitian ini adalah didapatkannya karakteristik kebutuhan media pop culture up rumah adat Jawa untuk pembelajaran menyusun teks deskripsi: (1) aspek penyajian isi/materi adalah penyajian gambar pop up beserta keterangan bagian-bagianya dan cara menyusun teks deskripsi; (2) aspek bahasa dan keterbacaan disesuaikan dengan kemampuan peserta didik; (3) aspek tampilan 2D, perpaduan warna, serta jenis huruf disesuaikan. Penilaian terhadap media pop culture up rumah adat Jawa: (1) aspek grafika mendapat nilai 79,1 dengan kategori baik, (2) aspek penyajian isi/materi mendapat nilai 75,2 dengan kategori baik, dan (3) aspek bahasa dan keterbacaan mendapat nilai 81,6 dengan kategori sangat baik.
\end{abstract}

Kata Kunci: media pop culture up, rumah adat Jawa, menyusun teks deskripsi.

\begin{abstract}
The purposes of this research is to describe characteristic of Javanese traditional house pop culture up media needed for development teaching to arrange an description text for $7^{\text {th }}$ grade Junior High School students, media development, and describes the assessment of this medium. The design used in this research was research and development (R\&D). The data source was students, teachers, and experts. The data collecting technique was questionnaire technique. Data were be analyzed by qualitative descriptive analyze technique. The results showed that the characteristics of need were (1) present materials aspect is to present pop up picture with the detail parts and how to arrange an description text; (2) language and reading aspect is suitable for students skill; (3) visual aspect is $2 \mathrm{D}$, full colour, and suitable font. The assessment were (1) visual aspect on this medium was achieved score 79,1 (good category), (2) present materials aspect was achieved score 75,2 (good category), and (3) language and reading aspect was achieved score 81,6 (very good category).
\end{abstract}

Keywords: pop culture up media, Javanese traditional house, arranging of description text.

\section{PENDAHULUAN}

Suatu pembelajaran dikatakan berhasil apabila peserta didik dapat memahami dan melakukan apa yang disampaikan oleh guru. Untuk mencapai keberhasilan pembelajaran, proses pembelajaran membutuhkan media pembelajaran karena media pembelajaran merupakan salah satu komponen yang sangat penting dan berpengaruh dalam pembelajaran. Media pembelajaran berfungsi sebagai penyalur pesan antara peserta didik dengan materi yang 
2 Ambarsari \& Hartono, Pengembangan Media Pop Culture Up Rumah Adat Jawa untuk Pembelajaran Menyusun Teks Deskripsi Pada Peserta Didik Smp Kelas VII

disampaikan oleh guru. Selain itu, media pembelajaran berfungsi sebagai pendukung pemahaman pesereta didik terhadap materi ajar yang ingin dikuasai.

Media pembelajaran harus dapat berfungsi dengan baik. Karena itu, media pembelajaran harus memuat materi yang lebih sistematis agar pembelajaran berlangsung dengan efektif. Selain itu, media pembelajaran harus dapat memberikan pengalaman yang menyenangkan dan dapat memenuhi kebutuhan peserta didik yang memiliki kemampuan berbeda-beda. Hal itu seperti yang dikemukakan oleh Hamalik (dalam Arsyad 2003:15) bahwa pemakaian media pembelajaran dalam proses belajar mengajar dapat membangkitkan keinginan dan minat yang baru, membangkitkan motivasi dan rangsangan kegiatan belajar peserta didik. Penggunaan media pembelajaran pada tahap orientasi pembelajaran akan sangat membantu keefektifan proses pembelajaran dan penyampaian pesan dan isi pelajaran saat itu.

Hasil observasi pada proses pembelajaran dan wawancara dengan guru mata pelajaran bahasa Indonesia, disimpulkan bahwa dalam proses pembelajaran menyusun teks deskripsi pada kelas VII SMP di sekolah masih ditemukan beberapa permasalahan yang menyebabkan pembelajaran kurang optimal. Permasalahan tersebut berasal dari guru, yaitu pada cara guru menyampaikan materi dengan metode ceramah dan berpusat pada satu sumber. Selain itu, media yang digunakan oleh guru kurang menarik perhatian dan memberi motivasi pada peserta didik dalam pembelajaran menyusun teks deskripsi.

Salah satu cara memberi kesan bagi peserta didik dalam pembelajaran ialah mendorong peserta didik untuk berbuat dan memanfaatkan sebanyak mungkin indra yang dimiliki. Kesan tersebut dapat ditimbulkan melalui media yang digunakan, seperti media buku pop up. Penggunaan media pembelajaran buku pop up dirasa sangatlah diperlukan dalam pembelajaran. Buku pop up hadir sebagai media pembelajaran yang berupa buku dengan gambar timbul yang memberikan gambar tiga dimensi ketika buku tersebut dibuka. Buku pop up merupakan sebuah buku yang memiliki bagian yang dapat bergerak atau memiliki unsur 3 dimensi. Sekilas buku pop up hampir sama dengan origami, yaitu kedua seni ini mempergunakan teknik melipat kertas (Nancy dan Rondha dalam Khoirotun, dkk. 2014). Buku рор ир dibuat dengan memberikan kejutan-kejutan dalam setiap halamannya sehingga dapat membuat rasa kagum bagi siapa saja yang membuka dari halaman yang satu ke halaman selanjutnya.

Penelitian tentang pemakaian media buku pop up untuk pembelajaran pernah dilakukan oleh Noviyanti et al. (2013) dalam penelitiannya yang berjudul "Keefektifan Kartu Bergambar Berbentuk Pop Up Card pada Pembelajaran Siswa SMP”. Dalam penelitian tersebut media 
yang dikemas dalam bentuk pop up card mampu meningkatkan kemampuan belajar siswa. culture up untuk peserta didik SMP dalam menyusun teks deskripsi. Penelitian lain yang berkaitan dengan pop up dilakukan oleh Hawarya (2014) yang berjudul "Pengembangan Popup Module Pembelajaran Biologi pada Materi Pencemaran dan Pelestarian Lingkungan untuk Siswa SMA Kelas X". Hasil penelitian tersebut menunjukkan bahwa pop up efektif digunakan untuk membantu peserta didik memahami materi.

Berdasarkan uraian di atas, penelitian ini berusaha mengembangkan media pembelajaran dengan mnjawab permasalahan: (1) bagaimanakah analisis kebutuhan peserta didik dan guru terhadap media pop culture up rumah adat Jawa untuk pembelajaran menyusun teks deskripsi peserta didik SMP kelas VII?; (2) bagaimanakah prototipe media pop culture up rumah adat Jawa untuk pembelajaran menyusun teks deskripsi pada peserta didik SMP kelas VII?; (3) bagaimanakah hasil penilaian dan perbaikan prototipe media pop culture up rumah adat Jawa untuk pembelajaran menyusun teks deskripsi pada peserta didik SMP kelas VII?.

Adapun tujuan penelitian ini, yaitu (1) mendeskripsi karakteristik kebutuhan peserta didik dan guru terhadap media pop culture up rumah adat Jawa untuk pembelajaran menyusun teks deskripsi peserta didik SMP kelas VII; (2) mendeskripsi prototipe media pop culture up rumah adat Jawa untuk pembelajaran menyusun teks deskripsi pada peserta didik SMP kelas VII?; dan (3) mendeskripsi hasil penilaian dan perbaikan prototipe media pop culture up rumah adat Jawa untuk pembelajaran menyusun teks deskripsi pada peserta didik SMP kelas VII.

\section{METODE PENELITIAN}

Penelitian ini dilakukan dengan menggunakan pendekatan Research and Development $(R \& D)$. Dalam penelitian ini, terdapat lima tahapan: (1) potensi dan masalah, (2) pengumpulan data, (3) desain produk, (4) validasi desain, dan (5) revisi desain.

Sumber data penelitian ini terdiri atas tiga sumber, yaitu (1) data ketersediaan dan kondisi bahan ajar, yaitu siswa dan guru; (2) data kebutuhan, yaitu siswa dan guru; dan (3) data validasi prototipe, yaitu guru dan dosen ahli. Intrumen yang digunakan dalam penelitian ini adalah pedoman observasi, wawancara, dan angket.

Teknik pengumpulan data yang digunakan untuk penelitian ini, di antaranya observasi, wawancara, dan kuesioner atau angket. Observasi digunakan sebagai pengamatan terhadap pembelajaran menyusun teks deskripsi oleh guru dan peserta didik. Teknik wawancara ini dilakukan untuk memperoleh data mengenai subjek penelitian dan kondisi pembelajaran. Teknik angket dipilih karena keefektifannya untuk menghimpun data kebutuhan. Angket yang 
4 Ambarsari \& Hartono, Pengembangan Media Pop Culture Up Rumah Adat Jawa untuk Pembelajaran Menyusun Teks Deskripsi Pada Peserta Didik Smp Kelas VII

digunakan terdiri atas angket kebutuhan media untuk siswa dan guru serta angket uji validasi media oleh guru dan ahli. Teknik analisis data yang dilakukan dalam penelitian ini adalah menggunakan teknik analisis deskriptif kualitatif.

\section{HASIL PENELITIAN DAN PEMBAHASAN}

\section{Hasil Penelitian}

\section{Karakteristik Kebutuhan Media Pembelajaran oleh Peserta Didik dan Guru}

Hasil penelitian yang telah dilakukan diperoleh data tentang karakteristik kebutuhan peserta didik dan guru terdiri atas aspek penyajian isi/materi, kegrafikaan atau desain media, dan bahasa dan keterbacaan media. Pertama, pada aspek penyjian isi/materi, diperoleh data karakteristik kebutuhan media pembelajaran, yaitu (1) judul media Media Pembelajaran Pop Culture Up Rumah Adat Jawa, Menyusun Teks Deskripsi, SMP/MTs Kelas VII disesuaikan dengan isi media yang terdiri atas pengenalan awal, gampar pop up rumah adat Jawa, bagianbagian rumah adat Jawa, struktur teks deskripsi, dan teks deskripsi; (2) ilustrasi pembuka yang disusun sesuai dengan tema dan ditulis menggunakan bahasa komunikatif; (3) gambar pop up pembuka disajikan untuk menarik perhatian peserta didik dengan menghadirkan gambar orang berpakaian adat yang muncul saat buku dibuka; (4) halaman gambar pop up rumah adat Jawa disajikan dengan gambar muncul secara vertikal/tegak lurus saat buku dibuka; (5) bagianbagian rumah adat Jawa disajikan dengan gambar-gambar yang disertai nama bagian rumah dan keterangnnya; dan (6) teks deskripsi ditulis menggunakan bahasa yang mudah dipahami oleh peserta didik yang disertai dengan pemahaman struktur teks deskripsi.

Kedua, pada aspek kegrafikaan, diperoleh data karakteristik kebutuhan media pembelajaran, yaitu (1) tampilan fisik media disesuaikan dengan tema, menggunakan kombinasi warna yang menarik, dan gambar yang sesuai; (2) komposisi warna yang dikombinasikan terdiri atas warna coklat, biru, dan merah muda; (3) ilustrasi untuk mendukung tampilan fisi media dibuat sesuai dengan tema dengan gambar yang menarik; (4) ukuan buku yang diharapkan adalah besar seperti buku paket atau ukuran A4; dan (5) jenis dan ukuran huruf pada media yang digunakan adalah jenis huruf comic sans ms dengan ukuran 14pt.

Ketiga, pada aspek bahasa dan keterbacaan, diperoleh data karakteristik kebutuhan media pembelajaran, yaitu (1) ragam bahasa yang digunakan untuk prototipe media adalam ragam bahasa santai; (2) penggunaan kata/diksi dipilihkan kata-kata yang sesuai dengan tingkat kemampuan pesrta didik dan mudah dipahami; dan (3) sapaan yang digunakan dalam media adalah kata sapa kamu. 
Dengan dasar data di atas, disimpulkan bahwa karakteristik kebutuhan dalam perencanaan penyusunan media pembelajaran dibutuhkan konsep dan rancangan media pembelajaran. Karakteristik konsep media pembelajaran meliputi (1) penyajian materi untuk menyusun teks deskripsi menggunakan bahasa yang mudah dipahami dengan menggunakan bahasa yang baku dan komunikatif; (2) penyajian gambar pop up rumah adat Jawa dibuat dengan tampilan 2D; dan (3) tampilan media didesain dengan menambahkan gambar, perpaduan warna, dan bentuk tulisan yang menarik.

\section{Prototipe Media Pop Culture Up Rumah Adat Jawa}

Prototipe media pop culture up rumah adat Jawa untuk pembelajaran menyusun teks deskripsi pada peserta didik SMP kelas VII dibuat berdasarkan prinsip-prinsip pengembangan. Bagian dari prototipe bahan ajar tediri atas tiga bagian, yaitu bentuk fisik media, sampul media, dan isi media. Berikut adalah penjabaran dari tiap-tiap bagian.

Bagian pendahuluan buku media pop culture up rumah adat Jawa ini berisi tentang pengenalan awal mengenai warisan budaya yang harus dilestarikan. Salah satu warisan budaya yang harus dilestarikan adalah rumah adat. Selain itu di dalam pendahuluan disajikan ajakan kepada peserta didik untuk menyusun teks deskripsi. Pada bagian pendahuluan ini pengguna media akan dikejutkan dengan animasi orang berpakaian adat yang muncul ke atas ketika buku dibuka.

Bagian isi terdapat gambar pop up rumah adat Jawa "Joglo" yang telah didesain sedemikian rupa. Gambar pop up rumah adat Jawa dibuat dengan tampilan vertikal/tegak ketika buku dibuka. Bagian selanjutnya adalah penjelasan bagian-bagian ruang rumah adat Jawa yang meliputi; saka guru, tumpangsari, pendapa, pringgitan, senthong, dan pekiwan. Pada bagian isi media pop culture up rumah adat Jawa ini terdapat bagian yang menjelaskan struktur teks deskripsi dan susudan teks deskripsi yang sudah sesuai dengan struktur.

\section{Penilaian dan Perbaikan Media Pop Culture Up Rumah Adat Jawa}

Penilaian terhadap media buku pop culture up rumah adat Jawa untuk pembelajaran menyusun teks deskripsi pada peserta didik SMP kelas VII dilakukan oleh guru pengampu mata pelajaran bahasa Indonesia dan dosen ahli. Hasil penilaian prototipe media diperoleh, yaitu (1) aspek grafika, nilai rata-rata dari kelima validator adalah sebesar 75 dengan kategori baik, (2) aspek penyajian isi/materi, nilai rata-rata dari kelima validator adalah sebesar nilai 73 
6 Ambarsari \& Hartono, Pengembangan Media Pop Culture Up Rumah Adat Jawa untuk Pembelajaran Menyusun Teks Deskripsi Pada Peserta Didik Smp Kelas VII

dengan kategori baik, dan (3) aspek bahasa dan keterbacaan, nilai rata-rata dari kelima validator adalah sebesar nilai 81 dengan kategori sangat baik.

Adapun hasil penilaian yang dilakukan oleh para validator, dilakukan perbaikan terhadap media pop culture up rumah adat Jawa. Perbaikan yang dilakukan atas saran validator meliputi dua aspek, yaitu aspek substansi materi dan aspek tampilan. Berikut ini adalah tabel perbandingan sebelum dan sesudah validasi prototipe.

Tabel 1. Perbandingan Sebelum dan Sesudah Validasi Prototipe Media Pop Culture Up Rumah Adat Jawa untuk Pembelajaran Menyusun Teks Deskripsi pada Peserta Didik SMP Kelas VII

\begin{tabular}{|c|c|c|}
\hline No & Sebelum & Sesudah \\
\hline 1 & 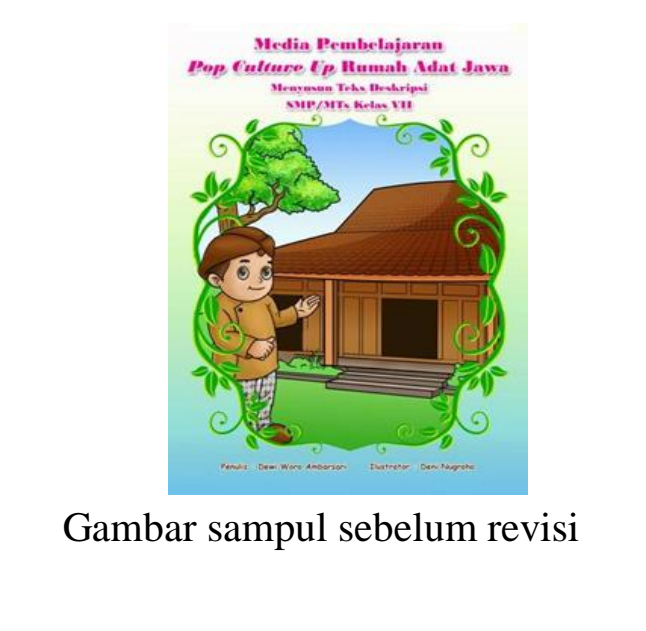 & sesudah revisi \\
\hline 2 & $\begin{array}{l}\text { GuMAн JоGıо } \\
\text { Gambar bagian-bagian rumah }\end{array}$ & $\begin{array}{l}\text { and } \\
\text { Gambar bagian-bagian rumah sesudah } \\
\text { revisi }\end{array}$ \\
\hline
\end{tabular}




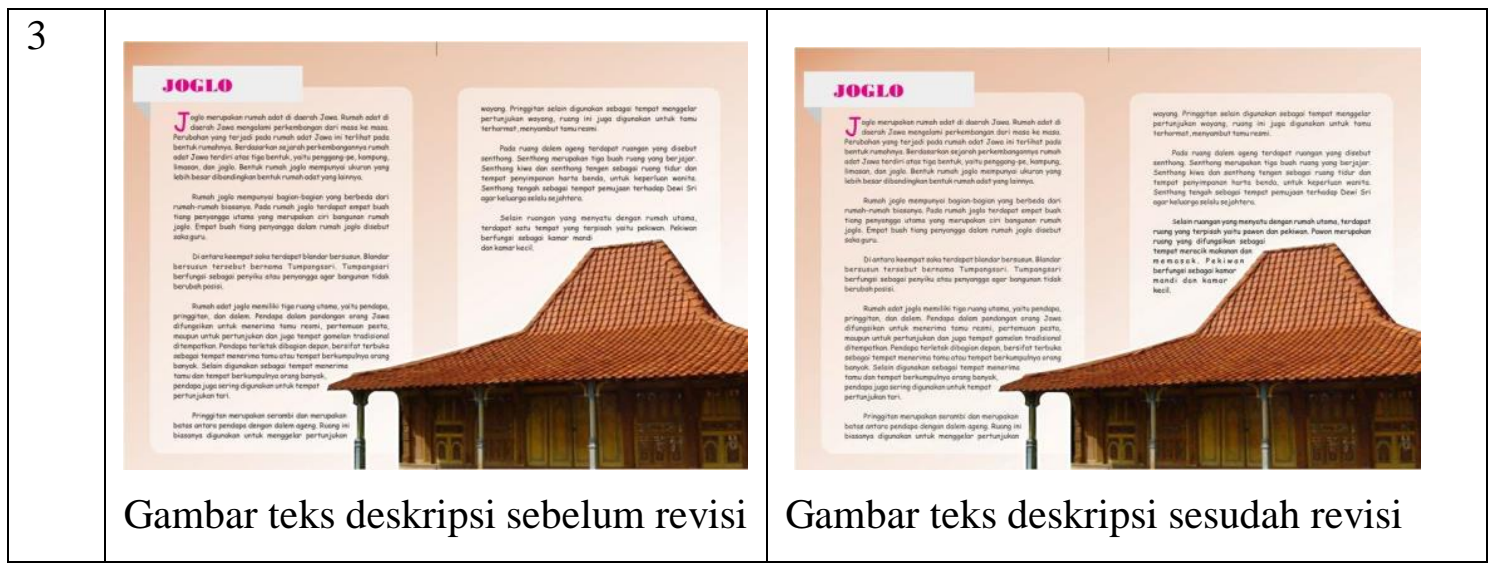

\section{Pembahasan}

Berdasarkan hasil penelitian, dapat diketahui bahwa dari serangkaian tahapan pengembangan yang dilakukan dalam penelitian ini telah dihasilkan produk berupa media pop culture up rumah adat Jawa yang telah melalui tahap ui validasi oleh ahli. Media yang dihasilkan dalam penelitian ini berupa media gambar rumah adat Jawa yang berbentuk pop up untuk membantu peserta didik dalam menyusun teks deskripsi.

Kelebihan yang dimiliki oleh produk media ini dapat dijadikan alternatif pilihan media dalam pembelajaran menyusun teks deskripsi agar tidak bosan dan jenuh. Hal tersebut dikarenakan fungsi media dalam kegiatan pembelajaran merupakan bagian yang sangat menentukan efektivitas dan efisiensi pencapaian tujuan pembelajaran.

Lebih lanjut Levie \& Lentz (dalam Arsyad 2011:16) mengemukakan empat fungsi media pembelajaran, khususnya media visual, yaitu fungsi atensi, fungsi afektif, fungsi kognitif, fungsi kompensatoris. Fungsi atensi media visual merupakan inti, yaitu menarik dan mengarahkan perhatian siswa untuk berkonsentrasi kepada isi pelajaran yang berkaitan dengan makna visual yang menampilkan atau menyertai teks materi pelajaran. Fungsi afektif media visual dapat terlihat dari tingkat kenikmatan peserta didik ketika belajar (atau membaca) teks yang bergambar. Fungsi kognitif media visual terlihat dari temuan-temuan penelitian yang mengungkapkan bahwa lambang visual atau gambar memperlancar pencapaian tujuan. Fungsi kompensatoris media pembelajaran terlihat dari hasil penelitian bahwa media visual yang memberikan konteks untuk memahami teks bagi peserta didik yang lemah dalam membaca untuk mengorganisasikan informasi dalam teks dan mengingat kembali.

Media ini dibuat melalui proses analisis kebutuhan peserta didik dan guru, pembuatan prototipe media, penilaian/validasi prototipe oleh guru dan ahli, dan perbaikan produk media. Hasil penilaian prototipe menunjukkan bahwa media ini memiliki nilai yang baik dari guru dan 
8 Ambarsari \& Hartono, Pengembangan Media Pop Culture Up Rumah Adat Jawa untuk Pembelajaran Menyusun Teks Deskripsi Pada Peserta Didik Smp Kelas VII

ahli. Melalui proses tersebut produk media pop culture up rumah adat Jawa dinilai layak untuk digunakan dalam pembelajaran, sehingga peserta didik dapat menyusun teks deskripsi dengan baik dan benar.

\section{PENUTUP}

\section{Simpulan}

Simpulan yang diperoleh dari penelitian ini mencakupi tioga hal. Pertama, karakteristik kebutuhan media menurut peserta didik dan guru mencakupi tiga aspek. Pada aspek penyajian isi/materi menurut peserta didik dan guru, hendaknya materi dan gambar dibuat lebih jelas agar mudah dipahami. Pada aspek bahasa dan keterbacaan menurut peserta didik dan guru, media pembelajaran memiliki ragam bahasa dan pilihan diksi yang mudah dipahami dan sesuai dengan jenjang kelas peserta didik. Pada aspek grafika, media pembelajaran disusun dalam bentuk buku A4, dengan jenis font Comic San Ms ukuran 14pt. Kedua, prototipe media disusun dan dikembangkan sesuai dengan karakteristik dan prinsip pengembangan media. Secara umum dapat diketegorikan menjadi tiga bagian meliputi (a) bentuk fisik, (b) sampul buku, dan (c) muatan isi/materi inti. Selain itu, media juga dikembangkan berdasarkan prinsip-prinsip pengembangan media. Pada aspek penyajian isi/materi didasarkan pada prinsip self instructional dan sistematis. Pada aspek bahasa dan keterbacaan menggunakan prinsip adaptif, konsistensi, dan relevansi. Pada aspek kegrafikaan menggunakan prinsip konsistensi dan relevansi. Ketiga, penilaian media pop culture up rumah adat Jawa untuk pembelajaran mneyusun teks deskripsi pada peserta didik SMP kelas VII dilakukan oleh guru pengampu mata pelajaran bahasa Indonesia dan dosen ahli. Hasil penilaian prototipe media mencakupi: (1) aspek grafika, nilai rata-rata dari kelima validator adalah sebesar 79,1 dengan kategori baik, (2) aspek penyajian isi/materi, nilai rata-rata dari kelima validator adalah sebesar nilai 75,2 dengan kategori baik, dan (3) aspek bahasa dan keterbacaan, nilai rata-rata dari kelima validator adalah sebesar nilai 81,6 dengan kategori sangat baik. Perbaikan yang dilakukan atas saran validator meliputi dua aspek. Kedua aspek tersebut adalah (1) aspek substansi materi, perbaikan dilakukan pada halaman bagian-bagian rumah adat Jawa yaitu dengan memberi tambahan satu bagian rumah pawon dan (2) aspek tampilan, perbaikan dilakukan dengan menghilangkan bingkai pada sampul dan mengganti gambar orang yang terdapat pada sampul. 


\section{Saran}

Saran yang direkomendaskan dari hasil penelitian ini adalah 1) guru mata pelajaran bahasa Indonesia hendaknya menerapkan pembelajaran menyusun teks deskripsi menggunakan media pembelajaran pop culture up rumah adat Jawa. Penggunaan media pembelajaran ini dapat memudahkan peserta didik dalam menyusun teks deskripsi. Mereka tidak perlu datang langsung ke lokasi rumah adat Jawa; 2) peneliti lain hendaknya menggunakan penelitian ini sebagai referensi atau bahan perbandingan dalam melakukan penelitian yang serupa namun dengan menggunakan tema dan jenis teks yang lain; dan 3) perlu dilakukan penelitian lebih lanjut untuk menguji keefektifan media pop culture up rumah adat Jawa sehingga media yang disusun dapat digunakan secara maksimal dalam pembelajaran.

\section{DAFTAR PUSTAKA}

Arsyad, Azhar. 2011. Media Pembelajaran. Jakarta: PT Raja Grafindo Persada.

Arsyad, Azhar. 2013. Media Pembelajaran. Jakarta: PT Raja Grafindo Persada.

Dalman. 2014. Keterampilan Menulis. Jakarta: PT Raja Grafindo Persada.

Kemendikbud. 2013. Kompetensi Dasar: Sekolah Menengah Pertama (SMP)/

Madrasah

Tsanawiyah (MTs). Jakarta: Kemendikbud.

Kemendikbud. 2014a. Buku Guru Bahasa Indonesia: Wahana Pengetahuan Kelas

VII.

Jakarta: Kemendikbud.

Kemendikbud. 2014b. Buku Siswa Bahasa Indonesia: Wahana Pengetahuan Kelas VII. Jakarta: Kemendikbud.

Haryadi. 2014. "Pengembangan Buku Ajar Membaca yang Bermuatan Kreativitas Berpikir dan

Nilai-nilai Karakter bagi Mahasiswa Pendidikan Bahasa dan Sastra Indonesia”. Disertasi. Universitas Negeri Semarang.

Hawarya, Yulisna, dan Agus Wasisto Dwi Doso Warso. 2014. "Pengembangan Pop-up

Module Pembelajaran Biologi pada Materi Pencemaran dan Pelestarian

Lingkungan untuk Siswa SMA Kelas X”. JUPEMASI- PBIO. Tahun 2014.

Volume 1. Nomor 1. Yogyakarta: Universitas Ahmad Dahlan, diunduh pada

Kamis, tanggal 28 Mei 2015 pukul 03.05 WIB.

Khoirotun, Anisah, Achmad Yanu Alif Fianto, dan Abdullah Khoir Riqqoh. 2014. "Perancangan Buku Pop-Up Museum Sangiran sebagai Media Pembelajaran tentang Peninggalan Sejarah”. Jurnal Desain Komunikasi Visual. Tahun 2014. 
10 Ambarsari \& Hartono, Pengembangan Media Pop Culture Up Rumah Adat Jawa untuk Pembelajaran Menyusun Teks Deskripsi Pada Peserta Didik Smp Kelas VII

Volume 2. Nomor 1. Surabaya: STMIK STIKOM, diunduh pada Sabtu, tanggal 7 Februari 2015 pukul 22.55 WIB.

Mahsun. 2014. Teks dalam Pembelajaran Bahasa Indonesia Kurikulum 2013. Jakarta: Raja Grafindo Persada.

Noviyanti, Linda, Kukuh Santoso, dan Noor Aini Habibah. 2013. "Keefektifan Penggunaan Kartu Bergambar Berbentuk Pop Up Card pada Pembelajaran Siswa SMP”. Jurnal Lembaran Ilmu Kependidikan. Tahun 2013. Nomor 2. Hlm. 76-83. Semarang: Universitas Negeri Semarang, diunduh pada Kamis, tanggal 28 Mei 2015 pukul 03.11 WIB. 